\title{
Glimpses of Sugarcane Varietal Screening and Improvement at Pusa, Bihar
}

\section{Balwant Kumar*}

SRI, DRPCAU, Pusa, Bihar, India

*Corresponding Author: Balwant Kumar, SRI, DRPCAU, Pusa, Bihar, India.

DOI: 10.31080/ASAG.2020.04.0793
Received: January 18, 2020

Published: February 08, 2020

(C) All rights are reserved by Balwant

Kumar.

\begin{abstract}
Sugarcane is primarily grown in nine states of India namely; Uttar Pradesh, Maharashtra, Andhra Pradesh, Bihar, Gujarat, Haryana, Karnataka, Punjab, and Tamil Nadu. During early 19th century sugarcane cultivation started as cash crop and number of sugar factories open keeping in view a glimpses of sugarcane varietal screening and Improvement has been reviewed and found that Bihar was rich in term of sugar factories and its $20-40 \%$ share in national sugar production was already reported. It was the introduction of Co seedling that replace local varieties under cultivation those were Co 210, Co213, Co 214, Co 313, Co 331, Co 513,Co 356, Co 395,Co 453,Co508 and CoK 32, Co 383, Co 622,Co 419,Co 617,Co1148 and Co 1158 while in present varietal scenario cultivated varieties are Co 0238, Co 0118, Co 98014, CoP 9301, CoLk 94184, CoP 112, CoSe 01434, CoP 09437, B0 154 and CoP 16437. It was also found that POJ 2878, Co285, Co281, CP 28/11, Co213 \& Co205 were mainly responsible for improvement in high yield and high sugar. The varietal development and evaluation of sugarcane varieties started in Bihar by after that Central Sugarcane Research Institute was established 1932 since then total 281 clones were developed at SRI, while several Sugarcane varieties of other place were also evaluated. AICRP on sugarcane under North Central Zone altogether 24 varieties were identified out of which 13 were notified for this zone while from SRI, total 10 varieties were identified among them two were notified. During last decade 44 clones were developed at SRI, Pusa and their evaluations were held time to time under water logging condition, red rot resistance and other biotic and abiotic stress as a result of hybridization followed by clonal selection in most of the genetic studied several clones are performing stable with high cane and sugar yield. This is a good sign for varietal improvement work in SRI, Pusa Bihar to release such technology for commercial cultivation which will overcome the past pride moment of sugarcane of Bihar again.

Keywords: Varieties Co, BO, CoP, CoSe, CoLk, SRI, Pusa, AICRP on Sugarcane, Bihar.
\end{abstract}

\section{Introduction}

Present cultivated varieties of Sugarcane (Saccharum sps. Hybrids) belongs to family Poaceae (Gramineae) and the tribe Andropogonae, is a major agricultural cash crop next to cotton in India. It act as a major industrial cash crop also, having potential to be a key crop in bio factory evolution as it produces high yield of valuable products like sugar, biofibres, waxes, bioplastic and biofuel In India altogether, 704 sugar factories are open while in Bihar out of 28 only 11 sugar mills are running along with some unorganised small and cottage industry like work has been seen like gur/jiggery and juice for livelihood of rural people of state.

Glimpses of sugarcane cultivation in Bihar has been traced out from early vedic period to middle of the 19th century. How Bihar fell from position of perhaps the primer to producer and supplier of sugar to the world to a position of only one unit among so many has been vividly described [1]. In British India during 1792, sugar rose by degrees to an enormous price in Great Britain. In consequence, the East India Company were called upon to lend their assistance to lowering of the price of sugar. On the $15^{\text {th }}$ of March 1792, his Majesty's Ministers to the British Parliament presented a report related to production of sugar in British India. Lieutenant J. Paterson, of then Bengal establishment, reported that sugar could be cultivated in Bihar with many superior advantages, and at less expense than in the West Indies. As a result, a number of sugar factories were established in Bihar. Presently, Sugarcane is the second most important industrial crop in the India, here sustaining millions of sugarcane farmers and livelihoods on sugarcane production. It was grown in 4.7 million hectares with total production of 355.09 million tonnes and productivity of 74.4 tonnes/ha in India whereas, Bihar has an area of 0.243 million hectare with production of 16.5 million tonnes and productivity 67.9 tonnes/ha [2]. Sugar industry is the only agro-based industry in Bihar needs its revitalization, Even in its present condition it plays significant role in the economy of the state, about 5 lakh cultivators grow sugarcane and factory supports employment generation up to 50 thousand workers annually. Graph 1 showed the relative trends of India and Bihar, no doubt India has made tremendous progress in sugarcane production during the last seven decades as a result the production increased from 35 to 356 Million tonnes after utilization of new sugarcane technologies mostly high yielder and high sugared varieties where as trends of sugar recovery has been found almost uniform i.e. around 10\% for India while in Bihar, it showed irregular trends, generally below the national average up to 2015 (Graph) but in recent year 2018-19 sugar recovery of the state rise up that is above than $10 \%$ just neck to neck of national level. 

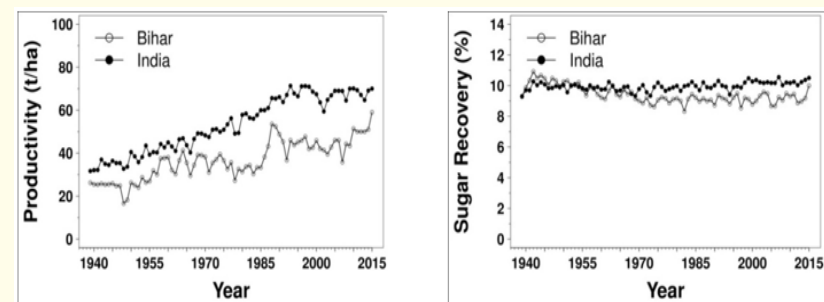

Graph 1: Productivity and sugar recovery trend of India vs Bihar (1940 to 2015).

During English empire, Bihar Sugar Industry occupied a place of pride in the rural economy of the state particularly North Bihar, right from early thirties when the state had 35 sugar factories out of total number of 130 factories in the country. Position gradually changed since then and in 2015-16, the state had only 11 functional and operating sugar factories out of 526 in the country [2]. Early nineteen to 1940 in Bihar the sugarcane area mostly covered by local land races viz, Mungo, Katar, Panshi, Bhoria, Hemja, Nargori, Sarbatia, Khosia, Sunable, Khelia and Paroria. The sugarcane varieties which were cultivation in Bihar till status of 20's were mainly of mungo group. The yield potential of those canes were mostly of low order (15 t/ha) with factory recovery not exceeding 8.0 percent therefore it was the urgent need to introduction of developed high yielder, high sugared sugarcane varieties of early maturity in cane growing area of Bihar to Sustain Sugar Industry in state. As we know C.A. Barber worked on many aspects of sugarcane breeding and in basic botany. He established a sugarcane research station that is now known as the Sugarcane breeding institute at Coimbatore (established in 1912) and along with T.S. Venkatraman developed hybrid sugarcane varieties suitable for India, under the Imperial Research Institute, Pusa, Bihar (established in 1905). These included hybrids between local and hardy canes from India which are now called Saccharum barberi after him and the tropical high-sugar yielding Saccharum officinarum which did not survive in the winter of northern India. This transfer of commercially useful traits from "noble" cane to Indian cane is referred to the 'Nobilization' of Indian canes. During that period in north India, Taylor and Woodhouse at Sabour, Bihar, had done much good work on sugarcane cross breeding. Mr. Wynne Sayer was an Imperial Agriculturist started the work on evaluation of Coimbatore seedlings at Pusa, Bihar with good effort during 1918-1920, by the sugar Bureau and the department of Agriculture. By the year 1923-24, the Coimbatore seedling namely Co 205, Co 210, Co 213 and Co 214 though high sugared and early in maturity could not find favour of growers while two varieties viz, Co 210 and Co 213 were covering up to $80 \%$ of total areas under sugarcane due to their high sugar and yield potential resulting successfully replaced the indigenous varieties. Before, 1930 the sugar industry was felt without on early variety of operate the factories economically in early part of their crushing season. The industry was badly in need of and early ripening variety. In order of tackle this problem the central Sugarcane Research Station was established in 1932 at Musheri, Muzaffarpur,
Bihar. A comprehensive account of the Coimbatore canes introduced in Bihar since 1923 to enhance sugar and yield potential. Twenty two outstanding varieties among Coimbatore canes from Co 205 to Co 350 were briefly described as regards their agricultural performance and juice quality along with some of their traits, the more important one being Co 205, Co 210, Co 213, Co 214, Co 281, Co 285, Co 299, Co 312, Co 313 and Co 331 during that period.

List of Combatore Seedlings imported in Pusa, Bihar in different years given below as indicated in scientific reports of the Imperial Agricultural Research Institute, New Delhi, Report of the Director 1935-36 [3].

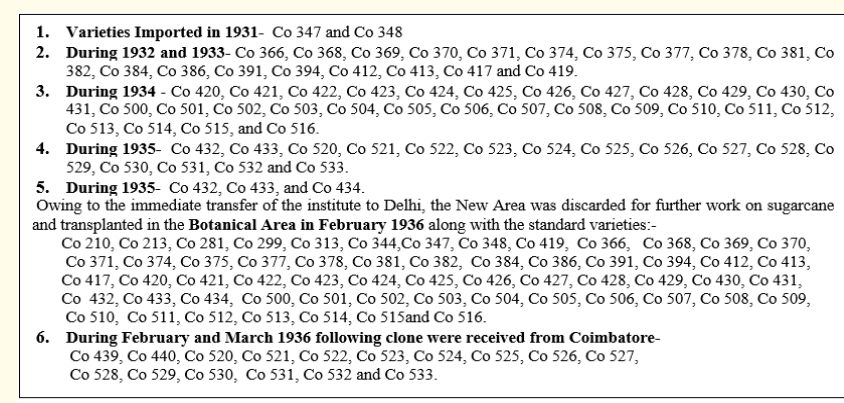

Figure a

A multidisciplinary sugarcane project, supported by the Indian central sugarcane committee was already operating since 1932 at the provincial government farm at Musheri, near Muzaffarpur which got the legacy of the erstwhile institute, minus the Phipp's laboratory. This project was later shifted to Pusa after the earthquake (1934). After the North Indian and Chinese cultivars have generally showed thinner stalks and leaves, flatter colors and lower sugar content than Nobles, a chromosome number $2 \mathrm{n}=80$ and a better adaptation to sub-tropical environments. They were formerly cultivated in mainland Asia, especially North India (Saccharum barberi) and South China, which are probably also where sugar-making industries were born. Nowadays, they are confined to germplasm collections. Five morpho-cytological groups have been described, Mungo, Saretha, Nargori, Sunnabile and Pansahi [4]. The binomial S. barberior Jesw usually refers to the first four groups, endemic to India. The fifth group is either included in $S$. barberior referred to as S. Sinense Roxb. It was common in China, and was introduced to India at the close of the 18th century. Saccharum barberi is a strong-growing species of grass in the genus Saccharum, the sugarcanes. It originates from northern India and has been exported to other countries and grown for the production of sugar. The species name commemorates C.A. Barber. Mr. Wynne Sayer, the Imperial Agriculturist, Pusa, was one of the earliest to take notice of the new Coimbatore canes. His interest in them facilitated their quick spread in Bihar "By his position", says Venakatraman, "he was able to introduce these canes into plantation and thus secure early recognition for the Coimbatore breeds".

In 1921, after two years of preliminary trials Wynne Sayer selected three varieties Co 210, Co 213 and Co 214 as likely to be the 
best for Bihar. The variety Co 214 was an early ripening cane (ready for crushing early in November) while Co213 and Co 210 were ripened in early December. Sugar factories in Bihar could start working at the earliest in the middle of December as the local cane. Hemja would not be fit for crushing earlier. Wynne Sayer found the new canes a means for extending the crushing season of factories by at least a month. The new varieties also possessed other advantages over hemja. They were hardy and could resist drought well. The hard outer rind of their shoots made them immune from attacks of Jackals and other animals. They gave good yield of cane, Co 213 recorded 800 maund per acre $(1$ maund $=40 \mathrm{~kg}$ : 40x800 $=32000$ kg per acre it means 80 tonne/ha.), Co 210 recorded 700 maund per acre (70t/ha.) and Co 214 recorded 600 maund per acre (60t/ ha) while local hemja seldom yielded more than 400 maund per acre (40t/ha). Twenty two outstanding varieties among Coimbatore canes from Co 205 to Co 350 were briefly described as regards their agricultural performance and juice quality along with same of their characters, the more important once being Co 205, Co 210, Co 213, Co 214, Co 281, Co 285, Co 299, Co312, Co 313 and Co 331. In nursery a large number of seedlings raised from fluff use to wither away. On examination the roots were found to have been attacked by nematode and a Pythium species. Chesnut compound (a mixture of ammonium carbonate and copper sulphate) mercuric chloride both 1:1000 given alternately once a week were able to control the disease [5]. The history of sugarcane cultivation in India in general and that of Bihar in particular has been traced out from very early times while a comprehensive account of the Coimbatore canes introduced in Bihar since 1923 is given in table 1. The later conditions which led to setting up sugarcane varieties advisory board in 1936 have also been discussed. A full account of the method and need of seed nursery development of promising varieties and withdrawal of discarded ones along with yield trials and mill test data of some of the promising varieties add much to the value of the article [6]. Related to cultural aspects prevailing in North Bihar such as preparatory cultivation, planting, earthing up, operation after earthing up, operation after harvest and improved implements [7]. Bakshi Ram and Rajesh Kumar [8] discussed the Role of Co varieties in sub-tropical India. After transfer of Imperial Institute from Pusa to New Delhi, the Central Sugarcane Research Institute shifted at Pusa had served to satisfy the problems of sugarcane growers in the state by providing novel technologies with prime objective to develop noble sugarcane varieties which can suit agro-climatic conditions viz, water logging, drought, salinity etc. to sustain sugar industry in Bihar. During early thirty a large number of Coimbatore seedling as well as Co clones/varieties had already been introduced from Coimbatore to Bihar evaluated in farmers field as well as in sugar factory area, after obtain significant yield and sugar performance some were released and other were used for studied on flowering behaviour as a result proper hybridization work was stated in 1937 at Pusa to development of BO clones. In nursery a large number of seedlings raised from fluff use to wither away. On examination the roots were found to have been attacked by nematode and a Pythium species. Chesnut com- pound (a mixture of ammonium carbonate and copper sulphate) Merecurichloride both 1:1000 given alternately once a week were able to control the disease [5].

The later conditions which led to setting up sugarcane varieties advisory board in 1936 have also been discussed. A full account of the method and need of seed nursery development of promising varieties and withdrawal of discarded ones along with yield trials and mill test data of some of the promising varieties add much to the value of the article [5]. In search of early maturity variety Co 331 and Co 313 were released in the year 1934. By the end of 1939 the coverage of these two varieties amounted to nearly $40 \%$. The red-rot epidemic of 1939-40 which completely wiped off Co 210 and Co 213 did not affect Co 229 and Co 313 due to the reason by the end of 1940-41 the coverage of these two varieties improved going up to 80 percent in most of the factories area.

The later introductions from Coimbatore i.e. Co 556 and Co 513 were of mid-season group with high tonnage which were multiplied fast and covered at least 33 percent of total crushing in a couple of years. Till, 1947, the Coimbatore originated varieties viz. Co 313, Co 513, Co 395, Co 453, Co 508 and CoK 32 were under commercial cultivation in traditional sugarcane growing belt of North and South Bihar.

In Bihar among the introduced varieties viz, Co 313 and Co 331 were released in 1934, Co 513 in 1937,Co 356 in 1940, Co 395, Co 453, Co508 and CoK 32 in 1943,Co 383 in 1944, Co 622 in 1951, Co 419 in 1953,Co 617 in 1961, Co1148 and Co 1158 in 1972 (Table 1). Till date SRI, Pusa, Bihar developed total 281 sugarcane clones (156 BO and $125 \mathrm{CoP}$ ) out of which first variety BO 11 was released in 1946 after that BO10 in 1947, BO 24 in 1951, BO 3, BO21 and BO 22 in 1953, BO 14 and BO 17 in 1955 and other released varieties are listed above in table 1 . Most of the important varieties released during early period which were namely; BO 3, BO 10, BO 11, BO 14,

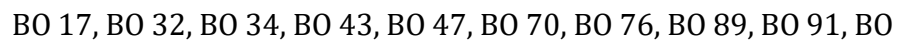
99, BO 109, BO 110 and BO 120. Among them the varieties BO 3, BO 32, BO 43, BO 76 had tolerance ability to water logging situation. The varieties BO 47 and BO 70 were most popular one, had once revolutionized the sugar industry through its high tonnage coupled with moderate sugar recovery. Another high recovery bearing varieties viz; BO 90, BO 99, BO 102, BO 120 and BO 128 were of early maturity having with higher tonnage. Wonder sugarcane variety B0 91 comes under mid late maturing group widely adapted under biotic as well as abiotic stresses, it has been performing well since last 41 years in Bihar, Eastern UP and West Bengal resisting it act as a national check under screening of varietal performance of elite clones during last three decades while in case of popularity for high sugar CoP 9301 rank first since 24 years. During last two decade early varieties viz, CoP 9301, BO 130 and BO 120 were performing very well s well as the varieties BO 145, BO 138 and BO 139 were also popular among the farmers field while recently new varieties BO 153 CoP 112 and CoP 16437 (Rajendra Ganna-1) of early maturity are gaining popular among the cane growers as well as the sugar factory management. The midlate maturing varieties namely, 


\begin{tabular}{|c|c|c|c|c|c|c|c|}
\hline Sl. No & Varieties & Parentage & Yield (t/ha) & Recovery (\%) & Year of release & Year of rejection & Remark \\
\hline 1. & Co 313 & Co 212 x Co 244 & 36.5 & 11.3 & 1934 & 1946 & Introduction \\
\hline 2. & Co 331 & Co 213 x Co 214 & 47.5 & 10.7 & 1934 & 1945 & Introduction \\
\hline 3. & Co 513 & PoJ 213 x Co 291 & 55.0 & 10.9 & 1937 & 1959 & Introduction \\
\hline 4. & Co 356 & PoJ 2725 x Sorghum durra & 51.0 & 10.0 & 1940 & 1944 & Introduction \\
\hline 5. & Co 395 & Co 243 x Co 244 & 55.0 & 10.0 & 1943 & 1953 & Introduction \\
\hline 6. & Co 453 & Black Cheribon x Co 285 & 52.0 & 10.5 & 1943 & 1956 & Introduction \\
\hline 7. & Co 508 & Co 214 x Co 214 & 54.0 & 10.8 & 1953 & 1959 & Introduction \\
\hline 8. & CoK 32 & PoJ 2878 x Co 331 & 56.0 & 11.2 & 1943 & 1959 & Introduction \\
\hline 9. & Co 383 & PoJ 2575 x Co 243 & 58.0 & 11.0 & 1944 & 1945 & Introduction \\
\hline 10. & BO 11 & Co 331 X PoJ 2878 & 55.0 & 10.9 & 1946 & 1959 & Developed \\
\hline 11. & BO 10 & Co 331 X PoJ 2878 & 50.0 & 10.7 & 1947 & 1972 & Developed \\
\hline 12. & BO 24 & Co 313 x Co 356 & 56.0 & 11.2 & 1951 & 1959 & Developed \\
\hline 13. & Co 622 & Co 421 x Co331 & 52.0 & 10.5 & 1951 & 1961 & Introduction \\
\hline 14. & BO 21 & Co 313 x Co 356 & 52.0 & 10.5 & 1953 & 1959 & Developed \\
\hline 15. & BO 22 & Not available & 54.0 & 10.8 & 1953 & 1959 & Developed \\
\hline 16. & Co 419 & PoJ 2878 x Co 290 & 60.0 & 11.0 & 1953 & 1969 & Introduction \\
\hline 17. & BO 03 & Co 312 X Co 326 & 55.0 & 10.5 & 1955 & 1977 & Introduction \\
\hline 18. & BO 14 & Co 331 X PoJ 2878 & 68.0 & 10.0 & 1955 & 1977 & Developed \\
\hline 19. & BO 17 & Co 331 X Co 326 & 62.0 & 10.0 & 1955 & 1978 & Developed \\
\hline 20. & BO 29 & B03 F.C & 60.0 & 10.0 & 1956 & 1977 & Developed \\
\hline 21. & BO 32 & Co 453 X BO 3 & 67.0 & 11.0 & 1959 & 1977 & Developed \\
\hline 22. & BO 34 & B015 F.C & 58.0 & 10.0 & 1959 & 1986 & Developed \\
\hline 23. & BO 43 & CP 28/21 X Co 285 & 58.0 & 11.0 & 1961 & 1986 & Developed \\
\hline 24. & BO 44 & Co 313 x BO 3 & 56.0 & 10.0 & 1961 & 1986 & Developed \\
\hline 25. & Co 617 & PoJ 2575 x Co 285 & 54.0 & 10.5 & 1961 & 1986 & Introduction \\
\hline 26. & BO 47 & Co 453 X BO 3 & 56.0 & 11.3 & 1963 & 1977 & Developed \\
\hline 27. & BO 50 & Co 453 X Co 513 & 50.0 & 10.8 & 1965 & 1972 & Developed \\
\hline 28. & B0 51 & Co 453 X Co 285 & 52.0 & 10.7 & 1965 & 1978 & Developed \\
\hline 29. & BO 65 & BO 14 X BO 3 & 58.0 & 10.3 & 1968 & 1978 & Developed \\
\hline 30. & BO 70 & BO 24 X BO 3 & 70.0 & 10.7 & 1972 & 1989 & Developed \\
\hline 31. & Co1148 & P 4383 x Co 301 & 50.0 & 10.3 & 1972 & 2000 & Introduction \\
\hline 32. & Co 1158 & Co $421 \mathrm{GC}$ & 52.0 & 10.5 & 1972 & 2000 & Introduction \\
\hline 33. & BO 74 & BO $14 \times$ BO 22 & 55.0 & 10.2 & 1974 & 1978 & Developed \\
\hline 34. & BO 75 & BO $29 \times$ BO 43 & 62.0 & & 1974 & 1986 & Developed \\
\hline 35. & BO 76 & BO 32 Self & 60.0 & 10.0 & 1974 & 1986 & Developed \\
\hline 36. & CoP 1 & Co 969 X CoL 9 & 50.0 & 10.8 & 1974 & 1986 & Developed \\
\hline 37. & CoP 2 & Co 419 X BO 17 & 50.0 & 10.0 & 1974 & 1986 & Developed \\
\hline 38. & BO 84 & B0 14 X B034 & 52.0 & 10.3 & 1976 & 1986 & Developed \\
\hline 39. & BO 88 & Co 1207 X BO 47 & 58.0 & 10.8 & 1977 & 1986 & Developed \\
\hline 40. & BO 89 & B0 47 Self & 60.0 & 10.8 & 1977 & 1989 & Developed \\
\hline 41. & BO 90 & BO 47 Self & 70.0 & 11.0 & 1977 & 1989 & Developed \\
\hline 42. & BO 91 & BO 55 X B0 43 & 78.0 & 10.2 & 1978 & Continuing & Developed \\
\hline 43. & BO 99 & Co 1207 X BO 43 & 75.0 & 10.7 & 1978 & 2002 & Developed \\
\hline 44. & BO 104 & Co 1193 X BO 47 & 75.0 & 10.2 & 1984 & 1989 & Developed \\
\hline 45. & BO 106 & Co 1193 X BO 47 & 50.0 & 10.4 & 1984 & 1989 & Developed \\
\hline 46. & BO 108 & Co X $22431 \mathrm{FC}$ & 79.0 & 10.5 & 1984 & 2002 & Developed \\
\hline 47. & CoS 767 & Co $419 \times$ Co 313 & 70.0 & 10.5 & 1984 & 2002 & Introduction \\
\hline 48. & BO 102 & BO 47F.Cs (Field Cross) & 85.0 & 11.5 & 1986 & 2000 & Developed \\
\hline 49. & BO 109 & Co 1193 X BO 32 & 80.0 & 11.2 & 1986 & Continuing & Developed \\
\hline 50. & BO 110 & Co 1193 X BO 50 & 78.0 & 10.4 & 1988 & Continuing & Developed \\
\hline 51. & BO 116 & Co 1214 X BO 43 & 80.0 & 10.7 & 1989 & 2002 & Developed \\
\hline 52. & BO 120 & B0 91 X В0 43 & 85.0 & 11.0 & 1989 & 2004 & Developed \\
\hline 53. & BO 128 & BO 85 X BO 43 & 88.0 & 11.0 & 1993 & 2004 & Developed \\
\hline 54. & CoP9206 & CoC 671 X Co 1148 & 85.0 & 10.8 & 1994 & Continuing & Developed \\
\hline 55. & CoP9301 & CoC 671 X BO 99 & 88.0 & 11.0 & 1996 & Continuing & Developed \\
\hline 56. & CoP9302 & BO 91 X Co 62174 & 94.0 & 10.8 & 1996 & Continuing & Developed \\
\hline 57. & BO 130 & B0 91 X B0 43 & 90.0 & 10.5 & 1997 & Continuing & Developed \\
\hline
\end{tabular}

Citation: Balwant Kumar. “Glimpses of Sugarcane Varietal Screening and Improvement at Pusa, Bihar". Acta Scientific Agriculture 4.3 (2020): 01-12. 


\begin{tabular}{|c|c|c|c|c|c|c|c|}
\hline 58. & BO 136 & BO 89 F.Cs (Field Cross) & 85.0 & 10.5 & 2002 & Continuing & Developed \\
\hline 59. & BO 137 & BO 106 F.Cs (Field Cross) & 88.0 & 10.4 & 2002 & Continuing & Developed \\
\hline 60. & BO 138 & Co 9701 X Co 1148 & 85.0 & 10.7 & 2003 & Continuing & Developed \\
\hline 61. & CoP 9702 & BO 99 X NC 0310 & 85.0 & 10.8 & 2003 & Continuing & Developed \\
\hline 62. & BO 139 & BO 109 X B0 43 & 84.0 & 11.0 & 2005 & Continuing & Developed \\
\hline 63. & BO 147 & B0 110 Self & 88.0 & 11.0 & 2005 & Continuing & Developed \\
\hline 64. & BO 145 & В0 110 X В0 121 & 82.0 & 11.0 & 2006 & Continuing & Developed \\
\hline 65. & BO 141 & $\begin{array}{l}\text { B0 } 89 \text { F.Cs } \\
\text { (Field Cross) }\end{array}$ & 88.5 & 11.2 & 2006 & Continuing & Developed \\
\hline 66. & BO 146 & BО 128 x B0 109 & 92.0 & 11.0 & 2008 & Continuing & Developed \\
\hline 67. & BO 153 & B0 131 Self & 87.0 & 10.8 & 2011 & Continuing & Developed \\
\hline 68. & CoP 2061 & CoLk 8102 x HR 83/65 & 98.0 & 10.5 & 2011 & CVRC & Developed \\
\hline 69. & CoP 112 & BO 91 x Co 62198 & 96.5 & 12.0 & 2015 & New Variety & Developed \\
\hline 70. & BO 154 & UP 98235 x UP 9742 & 104.0 & 11.3 & 2015 & New variety & Developed \\
\hline 71. & CoP 09437 & B0 91 GCs & 98.0 & 11.2 & 2016 & Identified & Developed \\
\hline 72. & CoP 16437 & CoSe 92423 x Co 1148 & 102.0 & 12.0 & 2017 & SVRC & Developed \\
\hline
\end{tabular}

Table 1A: Sugarcane Varieties released by SRI Pusa, Bihar since 1934 to 2019 with parentage.

(Sugarcane Varieties of Bihar - In past from 1934 to 1960 there were 22 varieties release by SRI, Pusa, it was a pride period of sugarcane in Bihar, while 21 varieties released from 1960 to 1985 in next two decade from 1985 to 2005, 18 varieties and during last fifteen years from 2005 to 2019, 11 varieties released all are listed above).

\begin{tabular}{|c|c|c|c|c|c|c|c|c|c|}
\hline \multirow{24}{*}{$\begin{array}{l}\text { Sugarcane } \\
\text { Varieties }\end{array}$} & \multicolumn{9}{|c|}{ During the year 1934 to 2019} \\
\hline & \multirow{2}{*}{$\begin{array}{c}\text { Sl. No } \\
1 .\end{array}$} & \multicolumn{2}{|c|}{ 1934-60 } & \multicolumn{2}{|c|}{$1960-85$} & \multicolumn{2}{|c|}{ 1985-2005 } & \multicolumn{2}{|c|}{ 2005-2019 } \\
\hline & & Co 313 & E & BO 43 & E & B0 104 & ME & BO 139 & E \\
\hline & 2. & Co 331 & E & BO 44 & E & BO 106 & $\mathrm{M}$ & BO 147 & ML \\
\hline & 3. & Co 513 & E & Co 617 & E & B0 108 & M & В0 145 & E \\
\hline & 4. & Co 356 & E & BO 47 & E & $\operatorname{CoS} 767$ & ME & BO 141 & ML \\
\hline & 5. & Co 395 & E & BO 50 & ME & BO 102 & $\mathrm{E}$ & B0 146 & ML \\
\hline & 6. & Co 453 & E & BO 51 & ME & BO 109 & $\mathrm{E}$ & B0 153 & $\mathrm{E}$ \\
\hline & 7. & Co 508 & E & BO 65 & M & BO 110 & ML & CoP 2061 & ML \\
\hline & 8. & CoK 32 & E & BO 70 & MS & BO 116 & $\mathrm{E}$ & CoP 112 & $\mathrm{E}$ \\
\hline & 9. & Co 383 & $\mathrm{E}$ & Co1148 & $\mathrm{M}$ & BO 120 & $\mathrm{E}$ & BO 154 & ML \\
\hline & 10. & BO 11 & $\mathrm{ME}$ & Co 1158 & $\mathrm{M}$ & B0 128 & E & CoP 09437 & ML \\
\hline & 11. & BO 10 & ME & BO 74 & $\mathrm{M}$ & CoP 9206 & ML & CoP 16437 & E \\
\hline & 12. & BO 24 & $\mathrm{M}$ & BO 75 & E & CoP 9301 & E & \multirow{11}{*}{ Total - } & \\
\hline & 13. & Co 622 & E & BO 76 & ME & CoP 9302 & ME & & \\
\hline & 14. & B0 21 & $\mathrm{ME}$ & CoP 1 & ME & BO 130 & $\mathrm{E}$ & & \\
\hline & 15. & BO 22 & ME & $\mathrm{CoP} 2$ & ME & B0 136 & $\mathrm{ME}$ & & \\
\hline & 16. & Co 419 & $\mathrm{E}$ & BO 84 & $\mathrm{M}$ & BO 137 & ML & & \\
\hline & 17. & BO 03 & MS & BO 88 & M & BO 138 & $\mathrm{E}$ & & \\
\hline & 18. & BO 14 & $\mathrm{M}$ & BO 89 & $\mathrm{M}$ & CoP 9702 & ML & & \\
\hline & 19. & BO 17 & $\mathrm{M}$ & BO 90 & $\mathrm{E}$ & \multirow{4}{*}{\multicolumn{2}{|c|}{ Total - 18}} & & \\
\hline & 20. & BO 29 & $\mathrm{~L}$ & BO 91 & $\mathrm{M}$ & & & & \\
\hline & 21. & BO 32 & M & BO 99 & $\mathrm{E}$ & & & & \\
\hline & 22. & BO 34 & $\mathrm{ME}$ & \multicolumn{2}{|c|}{ Total - 21} & & & & \\
\hline
\end{tabular}

Table 1B: Sugarcane Varieties released by SRI Pusa, Bihar since 1934 to 2019.

(Symbol of Maturity E: Early; ME: Mid Early; M: Main Season; ML: Midlate). 
BO 110, СoP 9206, BO 136, BO 137, BO 141, BO 146, CoP 9302, CoP 9702, CoP 2061, BO 154, and CoP 09437 are doing well in farmers field. The varieties BO 137, CoP 9301, BO 130 and BO 120 are popular for making khandsari (gur). CoP 2061 was released and notified during January 2015 while another midlate variety namely CoP 09437 was identified by CVRC, New Delhi for East U.P, Bihar, W.B. and Assam. Altogether 72 varieties were released by SRI, Pusa among them $47 \mathrm{BO}$ and 25 Co and its allied varieties were released by Institute since 1934 listed in table 1 . Selected best performing varieties of SRI, Pusa namely CoP 9301(E), CoP 2061(ML), CoP 112(E), BO 153(E) and 154(E) as given in table 2 which showed significant cane and sugar yield for its popularization will be done through participatory seed production involving sugarcane farmers. The varieties wise coverage area of sugarcane in Bihar during 2018 was recorded approx. 10\% for CoP 9301 while CoP 2061, CoP 112, B0154 and BO 153 lies below 10\%. The BO 110, BO91 and B0147 having a coverage area $20 \%$ in Bihar therefore it needs to replace by new varieties CoP 16437, CoP 112, CoP 2061, BO 154 and CoP 09437 as all of these bearing high cane and sugar yield while last three are performing very well under water logging condition. Presently new variety Rajendra Ganna-1(CoP 16437) gaining popularity among the farmers as well as sugar mills of Bihar due to its more tonnage i.e. $101 \mathrm{t} / \mathrm{ha}$ coupled with high sucrose percent $18.17 \%$ and widely adapted under changing climatic scenario of the state (Table 2). The scientists of AICRP on Sugarcane and SRI, Pusa have been continuously involved for development of improvement of sugarcane varieties and its production technologies starting from hybridization (at Coimbatore for Co clones while at Pusa for BO clones) followed by clonal selection and up to identification, release and notifications of a variety which takes 10 to 12 years. First six to seven years go for effective clonal selection of superior clones at respective research station the later half is spent on screening or evaluation of clones in comparison to the existing or ruling varieties under All India Coordinated Research Project at different locations in any particular zone and states zonal centres. After such an enormous effort a sugarcane breeder is in position to identify a promising clone that is fit to be release as a variety for commercial cultivation. The sugarcane department Government of Bihar also in favour of commercial cultivation of selected best performing 16 sugarcane varieties namely Co 98014, Co 0118, Co 0238, Co 0239, Co 0232, CoP 9301, CoLk 94184, CoS 8436,CoS 8432, CoP 2061, CoS 767,BO 153, BO 154, CoP 112, CoSe 01434 and CoSe 98259 and also provide subsidy on seed purchase during the crop season 2017-18. While in this year i.e. during 2019 only seven sugarcane variety viz, Co 0238, Co 0118, CoSe 96268, CoS 88230, CoJ 64,CoP 9301 and CoP 9301 in the place of 16 varieties of previous year. The details studies of sugarcane varieties either developed by AICRP(S) or SRI, Pusa showed significant yield and sugar potential on rest of the old non recommended varieties cultivated in sugarcane areas of Bihar now it is a good sign that Sugar Mills of the state got 10 to $11 \%$ sugar recovery in the year 2018 and even in Jan. 2019 some Sugar Mills are getting 11\% sugar recovery. Best performing 4 sugarcane varieties namely Co 8014, Co 0118, Co 0238 \& Co 0239 are introduced in Bihar as per the yield and sugar potential found in AICRP trial.
All India Coordinated Research Project on Sugarcane is working in the Country since 1970 through a network of Sugarcane Research Station of AICRP on Sugarcane, State Agricultural Universities (SAUs), State Government Departments and Non-Government Organizations. The project aims at pooling the research resources of the Country in a National grid for addressing the regional and national issues for improving the sugarcane production. At present, there are 22 regular centres and 14 voluntary centres across the country in five agro-climatic zones viz., Peninsular Zone, North West Zone, East Coast Zone, North Central Zone and North Eastern Zone for conducting research and multi-location testing of technology for wider adoption. Evaluation of locally adapted sugarcane varieties with improved yield and quality as well as resistance to biotic and abiotic stresses. Development of low cost technologies for sugarcane production. Intensifying and extending the networking facility and information generation for transfer of technology to the farmers and sugar industry of India are Mandates of AICRP on Sugarcane. As per the mandate, the main emphasis is laid on the development of improved varieties. After establishment of AICRP on Sugarcane in 1970, it was decided to supply fluff to the AICRP centres under "Fluff Supply Programme". Since the hybridization programme involved use of large number of parents, a National Hybridization Garden (NHG) facility was established in 1972 at ICAR-SBI, Coimbatore developed National Distant Hybridization Facility (NDHF) also at Agali, Palakkad (Kerala) where different species of Saccharum complex are maintained for hybridization work. These two national facilities are availed by the breeders of AICRP(S) centres for carrying out hybridization programme of their need based choice by effecting crossing NHG and/or NDHF every year. The fluff supply programme is an important component of Crop Improvement discipline as wider spectrum of genetic material is made available to the breeders. Regularly in every crossing programme Breeders of SRI, Pusa attempted the crosses utilising the wider spectrum of genetic material to full fill the objectives related development of high cane and sugar yield coupled with stress tolerance(biotic i.e. disease and pest and abiotic water logged, drought etc.) sugarcane variety for Bihar and North Central and eastern Zones. Every year, fluff of different crosses effected by the Breeders is supplied by ICAR-SBI, Coimbatore to the centres for raising of seedlings and selection of elite clones. For identification of promising crosses as per conducting zonal varietal trials, decision in first Workshop of AICRP on Sugarcane held at the Indian Institute of Sugarcane Research, Lucknow, 1970 was taken. The project on Zonal Varietal Trial (ZVT) was started by pooling the released varieties of each state in a particular zone with a view to evaluating them under varying conditions of the entire zone, so that proven varieties could be released by the other states also for commercial cultivation. The five zones identified in the country and the states included in each zone viz, North West Zone has five states Punjab, Haryana, Rajasthan, Uttar Pradesh (western and central) and Uttarakhand, North Central Zone: Uttar Pradesh (eastern), Bihar and West Bengal, North East Zone: Assam, East Coast Zone: Odisha, coastal Andhra Pradesh and coastal Tamil Nadu and Peninsular Zone: Gujarat, Madhya Pradesh, Chattisgarh, Maharashtra, Karnataka, interior plains of Andhra Pradesh, Telangana inte- 
rior plains of Tamil Nadu and Kerala. After evaluation top ranking clones are being proposed by the concerned breeder for identification of variety by Varietal Identification Committee ICAR, New Delhi. The identified clones are subsequently proposed by the concerned breeder for release and notification by Central SubCommittee on Crop Standards Notification and Release of Varieties for Agricultural Crops (Govt. of India). A total of 116 varieties have been identified since 1982 till now in different agro-climatic zones of the country. Bihar comes under North Central Zone and altogether 24 varieties were identified out of which 13 were notified for this zone. From SRI, Pusa total 10 varieties were identified viz, BO 90(E) and BO 100(ML) in 1982, B0 91(ML) in 1983, B0 109 (ML) and CoS 7918 (ML) in 1985, BO 120(E) in 1997, CoP 9103(ML) and BO 128(ML) in 1999, BO 146(ML) in 2006, CoP 2061 (CoP 06436 - ML) in 2013 and CoP 09437 in 2016 out of 10 varieties of SRI, Pusa two varieties viz, BO 128 and CoP 2061 got its notification by CVRC, New Delhi. Identified varieties from R.R.S. Motipur, Bihar (from 1985 to 2006 under SBI, Coimbatore while after 2006 to till date under IISR, Lucknow) there were six varieties viz, Co87263(E) and Co 87268 (E) in 1994, Co 89029(E) in 2001, CoLk 94184(E) in 2007, Co 0232(E) and Co 0233(ML) in 2008 after identification all these six varieties were got their notification. From GSSB\&RI, Seorahi eight varieties viz, CoS 7918 (ML) in 1985, CoSe 95422(E) and CoSe 92423(ML)in 2001, CoSe 96234(E) and CoSe 96436(ML) in 2002 CoSe 01421(E) in 2009,CoSe 05451(E) in 2012 and UP 09453(E) in 2017 were identified out of which five got notification namely CoSe 95422,CoSe 92423, CoSe 96234, CoSe 96436 and CoSe 01421. Selected best performing varieties are given in table 1 for its popularization would be done through participatory seed production, especially involving sugarcane farmers.

\begin{tabular}{|c|c|c|c|c|c|c|c|}
\hline \multirow[b]{3}{*}{1.} & \multirow{2}{*}{\multicolumn{2}{|c|}{$\begin{array}{l}\text { Variety/ } \\
\text { Maturity }\end{array}$}} & \multirow{3}{*}{$\begin{array}{l}\begin{array}{l}\text { Yield } \\
\text { t/ha. }\end{array} \\
76.30 \\
\end{array}$} & \multirow{3}{*}{\begin{tabular}{|c|} 
Sucrose\% \\
17.60 \\
\end{tabular}} & \multirow{3}{*}{$\begin{array}{c}\text { CCS t/ } \\
\text { ha. }\end{array}$} & \multicolumn{2}{|c|}{ Recommendation either Identified or Notified } \\
\hline & & & & & & \multirow{2}{*}{$\begin{array}{c}\text { CVRC }^{*} / \text { SVRC/RCM } \\
\text { (dentified and Notified }\end{array}$} & \multirow{5}{*}{$\begin{array}{l}\text { Area for cultivation } \\
\text { North West Zone }\end{array}$} \\
\hline & Co98014 & E & & & & & \\
\hline 2. & Co 0118 & E & 78.20 & 18.45 & 9.88 & Identified and Notified* & \\
\hline 3. & Co 0238 & E & 81.08 & 17.99 & 9.95 & Identified and Notified* & \\
\hline 4. & Co 0239 & $\mathrm{E}$ & 79.23 & 18.37 & 10.37 & Identified and Notified* & \\
\hline 5. & Co 0232 & $\mathrm{E}$ & 67.82 & 16.57 & 7.83 & Identified and Notified* & Bihar, U.P. W.B \& Assam \\
\hline 6. & CoP 9301 & E & 83.00 & 18.24 & 10.50 & Identified ${ }^{* *}$ & Bihar \\
\hline 7. & $\begin{array}{c}\text { CoLk } \\
94184 \\
\end{array}$ & $\mathrm{E}$ & 76.30 & 17.60 & 9.26 & Identified and Notified* & Bihar, U.P. W.B \& Assam \\
\hline 8. & $\operatorname{CoS} 8436$ & $\mathrm{E}$ & 70.00 & 17.80 & 8.89 & Identified & U.P. \\
\hline 9. & $\operatorname{CoS} 8432$ & $\mathrm{E}$ & 77.00 & 17.12 & 8.36 & Identified & U.P. \\
\hline 10. & CoP 2061 & ML & 74.50 & 17.35 & 9.18 & Identified and Notified* & Bihar, U.P. W.B \& Assam \\
\hline 11. & $\operatorname{CoS} 767$ & ML & 67.85 & 17.98 & 10.41 & Identified & U.P. \& Bihar \\
\hline 12. & BO 153 & $\mathrm{E}$ & 87.00 & 17.42 & 10.44 & Identified & Bihar \\
\hline 13. & BO 154 & ML & 104.00 & 17.47 & 11.97 & Identified** & Bihar \\
\hline 14. & CoP 112 & $\mathrm{E}$ & 96.50 & 17.48 & 11.94 & Identified ${ }^{* *}$ & Bihar, U.P. W.B \& Assam \\
\hline 15. & $\begin{array}{c}\text { CoSe } \\
01434 \\
\end{array}$ & $\mathrm{E}$ & 84.20 & 17.60 & 11.41 & Identified & Bihar, U.P. W.B \& Assam \\
\hline 16. & $\begin{array}{c}\text { CoSe } \\
98259 \\
\end{array}$ & E & 78.00 & 17.90 & 10.20 & Identified & U.P. \\
\hline 17. & CoP 16437 & $\mathrm{E}$ & 101.0 & 18.17 & 11.8 & SVRC & Bihar \\
\hline 18. & CoP 09437 & ML & 96.00 & 17.40 & 10.5 & Identified & Bihar, U.P. W.B \& Assam \\
\hline
\end{tabular}

Table 2: Well performing Sugarcane varieties of AICP(S) and SRI, Pusa for commercial cultivation in Bihar.

Sugarcane varieties namely Co98014, Co 0118, Co 0238, Co 0239, CoS 8436 and CoS 8432 were exhibited good performance in North West Zone involving Punjab, Haryana, Rajasthan, Uttar Pradesh (western and central) and Uttarakhand therefore with interest of farmers and mills, introduced in North Central Zone i.e. Uttar Pradesh (eastern) and Bihar, here varieties of SRI, Pusa showed stable performance more popular in the farmers field as well as reserved sugar factories area.

Altogether development of 55 Sugarcane Clones, namely, CoP 09436,CoP 09437, BO 153, BO 154, CoP 101, CoP 11436, CoP 11437, CoP11438, CoP 11439 CoP 11440, BO 155, CoP 12436, CoP 12437, CoP12438, CoP 12439 CoP 13436, CoP13437, CoP13438,
CoP 13439, CoP 14436, CoP14437, CoP14438, CoP 14439, CoP 15436, CoP 15437, CoP 15438, CoP 15439, CoP 15440, CoP 15441, CoP 16436, CoP 16437, CoP 16438, CoP 16439, CoP 16440, B0 156, CoP 17436, CoP 16437, CoP 17438, CoP 17439, CoP 17440, CoP 17441, CoP 17442, CoP 17443, CoP 17444, CoP 17445 CoP 17446, CoP 18436, CoP 18437, CoP 18438, CoP 19436, CoP 19437, CoP 19438, CoP 19439, CoP 19440 and CoP 19441 up to 2019 and most of these Sugarcane Clones were included in AICRP trials under North Central and North eastern Zones of India. After hybridization followed by clonal selection, selected $619,666,591,441$, 231, 441, 448 and 559 clones of Clonal generation one(C1) trials from hybrid Seedlings of the year 2012, 2013, 2014, 2015, 2016, 2017, 2018 and 2019, respectively from above selected 108, 127, 


\begin{tabular}{|c|c|c|c|c|c|c|c|c|c|c|c|}
\hline \multirow[b]{2}{*}{ Years } & \multicolumn{5}{|c|}{$\begin{array}{l}\text { From Seedling generation to different clonal } \\
\text { generations } \\
\text { Selection of best performing clones }\end{array}$} & \multicolumn{4}{|c|}{$\begin{array}{l}\text { Best yield and juice quality Sugarcane } \\
\text { clones Developed }\end{array}$} & \multicolumn{2}{|c|}{$\begin{array}{l}\text { Sugarcane Variety of SRI Pusa, } \\
\text { Released/Identified }\end{array}$} \\
\hline & $\begin{array}{l}\text { Seed- } \\
\text { ling }\end{array}$ & $\begin{array}{c}\text { Se- } \\
\text { lected }\end{array}$ & $\begin{array}{c}\text { Se- } \\
\text { lected }\end{array}$ & $\begin{array}{c}\text { Se- } \\
\text { lected }\end{array}$ & $\begin{array}{c}\text { Se- } \\
\text { lected }\end{array}$ & $\begin{array}{l}\text { To- } \\
\text { tal }\end{array}$ & Name of & the clones & $\begin{array}{l}\text { Inclu- } \\
\text { sion in } \\
\text { AICRP(S) }\end{array}$ & $\begin{array}{l}\text { University Re- } \\
\text { search Council }\end{array}$ & $\begin{array}{l}\text { AICRP/CVRC } \\
\text { for East U.P, }\end{array}$ \\
\hline 2009 & 23815 & 423 & 55 & 38 & 15 & 04 & $\begin{array}{c}\text { CoP } 091 \& \text { BO } \\
153\end{array}$ & CoP 092 \& BO 154 & 04 & B0146 & --- \\
\hline 2010 & 31933 & 536 & 101 & 48 & 10 & 01 & CoP 101 & & --- & --- & BO 146* \\
\hline 2011 & 60185 & 768 & 109 & 32 & 23 & 06 & $\begin{array}{l}\text { CoP } 111, \text { CoP } \\
112 \& \text { CoP } 113\end{array}$ & $\begin{array}{c}\text { CoP 114, CoP } 115 \\
\quad \& \text { BO } 155\end{array}$ & 06 & $\begin{aligned} \text { BO } 153 \\
\& \text { CoP } 2061\end{aligned}$ & --- \\
\hline 2012 & 53431 & 636 & 145 & 53 & 19 & 04 & $\begin{array}{c}\text { CoP } 121 \& \text { CoP } \\
122\end{array}$ & $\begin{array}{c}\text { CoP } 123 \& \text { CoP } \\
124\end{array}$ & 04 & --- & --- \\
\hline 2013 & 17458 & 719 & 127 & 64 & 23 & 04 & $\begin{array}{c}\text { CoP } 131 \& \text { CoP } \\
132 \\
\end{array}$ & $\begin{array}{c}\text { CoP } 133 \& \text { CoP } \\
134\end{array}$ & 04 & --- & --- \\
\hline 2014 & $\begin{array}{l}817 \\
\text { (Pusa } \\
\text { cross) }\end{array}$ & 666 & 154 & 62 & 18 & 04 & $\begin{array}{l}\text { CoP } 141 \& \text { CoP } \\
142\end{array}$ & $\begin{array}{l}\text { CoP } 143 \text { \& CoP } \\
144\end{array}$ & 04 & --- & --- \\
\hline 2015 & 58509 & 441 & 108 & 27 & 13 & 06 & $\begin{array}{l}\text { CoP } 151 \& \text { CoP } \\
152\end{array}$ & $\begin{array}{c}\text { CoP 153, CoP 154, } \\
\text { CoP } 155 \& \text { CoP } \\
156\end{array}$ & 06 & $\begin{array}{c}\text { BO } 154 \& \text { CoP } \\
112\end{array}$ & CoP $2061^{* *}$ \\
\hline 2016 & 26824 & 231 & 173 & 49 & 18 & 06 & $\begin{array}{c}\text { CoP 16436, } \\
\text { CoP16437 \& CoP } \\
16438 \\
\end{array}$ & $\begin{array}{l}\text { CoP } 16439, \text { CoP } \\
16440 \& \text { BO } 156\end{array}$ & 06 & --- & CoP 09437* \\
\hline 2017 & 40427 & 342 & 94 & 64 & 14 & 11 & $\begin{array}{c}\text { CoP } 17436, \\
\text { CoP } 17437, \\
\text { CoP } 17438, \\
\text { CoP } 17439, \\
\text { CoP } 17440 \& \\
\text { CoP17441 } \\
\end{array}$ & $\begin{array}{c}\text { CoP } 17442, \text { CoP } \\
17443, \mathrm{CoP} 17444 \\
\text { CoP } 17445 \& \text { CoP } \\
17446\end{array}$ & 07 & $\begin{array}{c}\text { Rajendra Ganna } \\
\quad 1 \\
\text { (CoP 16437) }\end{array}$ & \\
\hline 2018 & 23812 & 448 & 161 & 59 & 10 & 03 & $\begin{array}{l}\text { CoP } 18436, \mathrm{CoP} \\
18437 \& \mathrm{CoP} \\
18438 \\
\end{array}$ & --- & 03 & & \\
\hline 2019 & 40520 & 559 & 111 & 82 & 06 & 6 & $\begin{array}{c}\text { CoP } 19436, \\
\text { CoP } 19437 \& \\
\text { CoP19438 } \\
\end{array}$ & $\begin{array}{l}\text { CoP 19439, } \\
\text { CoP } 19440 \& \\
\text { CoP19441 }\end{array}$ & - & - & \\
\hline
\end{tabular}

Table 3: Varietal Improvement works of sugarcane at SRI, Pusa from 2009 to 2019.

(Symbol - University Research Council Meeting**, CVRC*)

$154,108,111,94,161$ and 111 clones for clonal generation second (C2) in respective years, in continuation of above further selection for clonal generation third (C3) 74, 53, 64, 62, 27, 64, 59 and 82 clones were selected as mentioned above respective years presented in table 3 .

Evaluation of sugarcane clone at SRI, Pusa as present research

1. Six high yielder with high sugared clones viz. P0J2878, Co285, Co281, CP28/11, Co213 \& Co205 were mainly responsible for improvement in high yield and high sugar along with stable performance ability among the North Central and North Eastern Zone of Sugarcane of north India after detail studies of ancestry.

2. Evaluation of early maturing sugarcane clones - During spring season 2017 at research farm of RPCAU, Pusa the clone CoP 16437 showed highest value for cane yield and sugar yield followed by CoP15437 \& CoSe12451.
3. Screening of variety under waterlogged -Four varieties viz. B0154, CoP092, CoX07067 and B0155 were identified as water-logging tolerant during 2012-13 and in another trial Evaluation of high sugared clone under water logged condition- Four clones namely CoX 12137, CoX 12164, CoX 12191 and CoX 12348 were selected as a water logging tolerant out of eighteen sugarcane clones including two checks (BO 91 and CoLk 94184) at Rajendra Agricultural University, Pusa, Bihar in a RBD with 3 replications during $2014-15$.

4. Evaluation of early maturing clone against red rot -The clones CoX 09726 (X indicates seedling number) significantly out yielded the check variety for both cane and sugar yield. The other clones CoX 09428, CoX 09715, CoX 09547, CoX 09647, CoX 09296 and CoX 09550 were statistically at par and also showed either resistant or moderately resistant reaction against red rot disease. 
5. Evaluation of sixteen early maturing sugarcane for high cane and sugar yield -Three Sugarcane Clones namely, CoP 15437, CoP 14436 and CoP 11437 were identified as high sugar and can yield bearing early maturing sugarcane during spring season 2016 these clones were planted at RPCAU, Pusa, farm Bihar.

6. Among the 15 test entries, the clone CoP16437 (Rajendra Ganna-1) showed highest value of cane yield and sugar yield followed by CoP15437 \& CoSe12451 evaluated during crop season $17-18$ at RPCAU, Pusa Farm.

7. Evaluation of thirteen mid late maturing sugarcane clones during 2018-19 at Research Farm, RPCAU, Pusa, Samastipur, Bihar a study on genetic variability, heritability and genetic advance for cane and sugar yield along with its component traits. Highly significant differences for all the characters were observed among the 13 clones under studied. Higher numerical values of phenotypic variances and co-variances with respect to its genotypic counterpart were recorded for all the traits indicating greater environmental influence on these traits for total variation. High heritability coupled with high genetic advance as percent of means were observed for sugar yield, cane yield, germination $\%$ at 45 days, cane height, single cane weight at harvest and fiber $\%$ at harvest, it indicates the presence of additive gene action therefore, clonal selection based on above said traits might be effective method for sugarcane improvement programme. These traits can be considered for further clonal selection and genetic improvement of mid late maturing sugarcane clones.

8. Evaluate of 18 clones during 2015-16 at RPCAU, Pusa was done on the basis of mean performance of cane yield as well as other productive traits under water logging condition, out of eighteen only four clones namely CoX 12137, CoX 12164, CoX 12191 and CoX 12348 were selected as a water logging tolerant. These clones may be utilize for further breeding programme so that recovery and productivity of sugarcane will be enhance for betterment of mankind. Aerial roots on node play important role under water logged.

9. Evaluate Sixteen early maturing sugarcane clones at Dr. R.P.C.A.U. Pusa, Bihar during 2016 found Six characters viz, cane yield, sugar yield, single cane weight, cane diameter, germination percentage at 90 days, shoots at 120 days as these characters showed high heritability coupled with genetic advance as per of mean. Well performance of the Clones namely, CoP 15437, CoP 14436 and CoP 11437 can be utilized for improvement of cane and sugar yield in early maturing sugarcane.

Improvement of sugarcane follow important considerations in choosing an appropriate variety include cane yield, juice quality, age group, suitability to the growing conditions viz., soil type, irrigation regime, season etc., ratooning potential, resistance to pests and diseases and adverse growing conditions. Some of the desirable varietal attributes one should look for are high yield potential, high sucrose content, good field appearance, higher tailoring capacity, medium thick to thick and long stalks, long internodes, erect growing habit, non-lodging, non-flowering or shy flowering, good ratooning ability, absence of spines on the leaf sheaths, absence of splits on the stalks, less bud sprouting and resistance to prevailing local problems. Varietal defects include lodging tendency, flowering propensity, disease susceptibility, cavity development, high fibre content, big and bulged buds which may be damaged during transportation, heavy spines on leaf sheath, drying of green top at maturity, tight leaf clasping, presence of heavy pith, growth cracks or splits. These defects may appear as minor and insignificant, at first, but they understandably draw the growers attention when the varieties come into cultivation. All the 14 selected early sugarcane varieties in above table showed high yield and sugar potential among them Co 0238 got popularity follow by Co 0118 , Co 98014 , CoP 9301 and CoLk 94184. The variety CoP 112, CoSe 01434, CoP 09437, BO 154 and CoP 16437 exhibited higher cane and sugar yield followed by suited to this zone under climatic changing scenario of Bihar, as erratic rainfall and water logging or drought condition. CoP 9301 has been found stable one and premium variety it favours more sugar and yield potential to fulfil the present need. Proper varietal proportion of area should be kept under early and mid- late maturing to ensure proper supply of cane of desired quality throughout the crushing period. Proper varietal proportion will not only increase the total sugar recovery but will also maintain it throughout the crushing season, a ratio of $60: 40$ has been suggested for early: mid-late ripening varieties for optimal performance and utilization of the crushing seasons. Within a maturity group, there should be more than one variety in the factory zone. It is for simple reason of providing insurance against epidemic of pest or disease of the crop, which may otherwise completely wipe out the crop. Such as Co 0238 may cultivate up to $30 \%$ coverage area of sugarcane growing area. Farmers and factory officers also encourages to increase the coverage area of Co 0238 in Bihar as they are getting more yield and sugar [9-43].

\section{Future strategies for sugarcane research}

Presently variety wise sugarcane coverage area in Bihar indicates good sign that it has been replacing old, obsolete and non recommended varieties by the improve high yielder and high sugared sugarcane varieties. During 2018 Dec., after collection of variety wise sugarcane coverage area from six sugar factories the varieties of SRI, Pusa cultivated in $24 \%$ area. Sugarcane is long duration crop maturing in 12-14 months. The planting method varies place to place and irregularity for harvesting based on maturity therefore, the states has to encourage recommended technologies and also for inter cropping to get higher returns. The main strategies to enhancing the sugar and yield potential of sugarcane in the Bihar are as under:

- Popularization of new selected varieties by providing support for breeder seed production follow participatory seed production to know the recommendations of AICRP and SRI, Pusa.

- Transfer of technologies related to mechanization and assured irrigation for sugarcane production through demonstration and training of farmers and extension workers must be updated. 
- Production of quality planting materials through tissue culture plantlets and bud chip for fast multiplication must be followed.

- $\quad$ Training to the field functionary and farmers for popularizing various technology including Ratoon Management and recommended doses of fertilizer, insecticides, pesticides, herbicides and other updated production technologies.

- Demonstration on intercropping in which potato, wheat, pulses and vegetable crop must be grown to get extra income.

- The states have flexibility to take support for sugarcane development for any recommended/proven technology/inputs under different projects.

Selected Sugarcane Varieties for commercial cultivation includes best performing based on evaluation in AICRP trial and State trial of SRI, Pusa given in table 1 will be helpful for enhancing the sugar and yield potential of sugarcane in Bihar.

Sugar and Sugarcane yield are influenced by many factors, including changing climatic scenario, landform, soil composition and structure, irrigation and drainage requirements, varieties, pests and diseases, management skill, labour availability and harvest- ing methods among them role of varieties are major which needs sugarcane improvement and its popularization through participatory seed production approaches specially in the state like Bihar. Sugarcane is used as raw material for sugar mills and main product produced are white sugar and other bye products. It generates employment opportunities for over six lakh families and 50 thousand skill and unskilled factory workers. Besides, it also generate man days for weaker section of society who remain engaged in different agricultural operation on farm, final disposal at factory gate and also in small scale Gur and Khandsari industries. The cane growers of Bihar are getting more than 600 crores as price of cane used for manufacturing of white sugar, Gur and Khandsari. About 15\% cane is used for seed, chewing and juice purposes. With an increase of one tonne in productivity of sugarcane, the cane grower of $\mathrm{Bi}$ har would be getting more than 15 crore as additional cane price. Through Bud Chip raising method $80 \%$ cane saved which will be utilised for Gur making because only buds are being used for planting with proper care. In general the seed rate of sugarcane is 50-60 quintal/ha as three budded setts used for seed. On weight basis only 15-18 kg buds are being chipped out from $100 \mathrm{~kg}$ of cane, it means saving of $82-85 \%$ cane value additional of Rs. $200-250$ crore will be saved for planting in 2 lakh hectare.

Private Sugar factories

\begin{tabular}{|l|c|c|c|c|}
\hline Sl. No & Factory & Capacity TCD & Existing capacity TCD & Cane requirement as per existing for 150 days (Tonnes) \\
\hline 1. & Sasamusa & 1000 & 3500 & 525000 \\
\hline 2. & Gopalganj & 1200 & 4000 & 600000 \\
\hline 3. & Sidhnealia & 1000 & 5000 & 750000 \\
\hline 4. & Bagaha & 1000 & 5000 & 750000 \\
\hline 5. & Harinagar & 3000 & 10000 & 1500000 \\
\hline 6. & Majhaulia & 2000 & 5000 & 750000 \\
\hline 7. & Hassanpur & 1300 & 5000 & 750000 \\
\hline 8. & Riga & 1200 & 5000 & 750000 \\
\hline 9. & Narkatiaganj & 1200 & 7500 & 1125000 \\
\hline 10. & Sughuli & 1100 & 3000 & 450000 \\
\hline 11. & Lauriya & 1750 & 5000 & 750000 \\
\hline
\end{tabular}

Sugar factories under Bihar state sugar corporation are closed since last two to four decades

\begin{tabular}{|l|c|c|c|}
\hline 12. & Hathua & 2000 & Closed since 20 - 40 years \\
\hline 13. & New Siwan & 800 & \\
\hline 14. & Siwan & 1000 & \\
\hline 15. & Motipur & 1200 & \\
\hline 16. & Goraul & 800 & \\
\hline 17. & Rayam & 925 & \\
\hline 18. & Lohat & 1320 & \\
\hline 19. & Sakri & 762 & \\
\hline 20. & Samastipur & 800 & \\
\hline 21. & Banmankhi & 1000 & \\
\hline 22. & Bihta & 1170 & \\
\hline 23. & Guraru & 850 & \\
\hline 24. & Warsalinganj & 700 & \\
\hline 25. & Morhowrah & 1100 & \\
\hline 26. & Chanpatia & 1650 & \\
\hline 27. & Motihari & 1700 & \\
\hline 28. & Bara Chakia & 1150 & \\
\hline & Total & 18227 & \\
\hline
\end{tabular}

Table 4: Crushing capacity and cane requirement for days of different Sugar factories. 


\section{Conclusion}

From reviewed of glorious past of sugarcane in Bihar and present varietal scenario indicates a good sign for sugarcane yield and sugar production in Bihar. It was a pride moment since 1900 to 1934 that the Imperial Agricultural Institute was established in Pusa Bihar and again central sugarcane sifted at Pusa since 1936 a sum total of 281 varieties were developed by the institute among them 44 in last decade. Altogether, 72 varieties were released by SRI, Pusa among them $47 \mathrm{BO}$ and $25 \mathrm{Co}$ and its allied varieties, after losing resistance against disease as well as inferior performance, time to time such varieties discarded/withdrawal from commercial cultivation. Presently Co 0238 got popularity follow by Co 0118 , Co 98014, CoP 9301, CoLk 94184, CoP 112, CoSe 01434, CoP 09437, BO 154 and CoP 16437 for commercial cultivation in Bihar. Several high yielder with high sucrose bearing clones after evaluation in water logging condition, red rot inoculation of early maturing are performing well and hope that in coming days further enhancement will be possible in term of cane and sugar yield for the benefits of farmers as well as sugar factories. There will be a chance with hope for opening of closed sugar mill or establishment of new one in Bihar.

\section{Bibliography}

1. Sarkar BN. "A short history of sugarcane cultivation in Bihar up to the middle of century". Agri and Livestock India 8.2 (1938): 167-173.

2. Indian sugar 2018-19. Anonymous, Department of Agriculture and Farmers Welfare, 2017-18.

3. Rao Bahadur B. Viswa Nath. "1935-36 Scientific reports of the Imperial Agricultural Research Institute, New Delhi, Report of the Director 1935-36". F.I.C.34-35.

4. Barber CA. "The classification of Indian Canes". The International Sugar Journal 24 (1922): 18-20.

5. Khanna KL. Sugarcane in Bihar: I - varietal position with special reference to procedure adopted in introducing new varieties. 8.3 (1947): 116-120.

6. Khanna KL. Sugarcane in Bihar: II- Cultural aspects. 8.3 (1947): 116-120.

7. Khanna KL. A preliminary note on the possibilities of breeding new varieties of sugarcane under North Bihar condition. Ibid., 7.1 (1937): 35-59.

8. Bakshi Ram and Rajesh Kumar. "Role of Co varieties in subtropical India”. Centenary souvenir 1912-2012. (2012): 103109.

9. Agrawal RK and Kumar Balwant. "Variability, heritability and genetic advance for cane yield and its contributing traits in sugarcane clones under waterlogged condition". International Journal of Current Microbiology and Applied Sciences 6.6 (2017): 1669-1677.
10. Agrawal RK and Kumar Balwant. "Characters association and their dissection through path analysis for cane and its component traits in sugarcane genotypes under water-logging condition". International Journal of Chemical Studies 6.4 (2018): 2327-2244.

11. Agrawal RK and Kumar Balwant. "Genetic Divergence in Sugarcane under Water- Logging Condition and Identification of Tolerant Clones". International Journal of Current Microbiology and Applied Sciences 6.7 (2017): 4044-4055.

12. Barber CA. "The origin of the sugar cane". The International Sugar Journal 22 (1920): 249-251.

13. Bal Krishna., et al. "Study of Genetic Variability among Midlate Maturing Sugarcane Clones for Different Yield and Juice Quality Traits under Waterlogged Condition". International Journal of Current Microbiology and Applied Sciences 6.7 (2017): 1390-1397.

14. George AG and Trubnee. Bihar Peasant Life, A Discursive Catalogue (1885) george a. Grierson, trubnee and Co., 57 \& 59, Ludgate Hill, London (1885).

15. Government of Bihar Department of Co-Operation and Sugarcane (Sugarcane Section) Report of the Cane and Development Committee, 1965, Printed by the Superintendent Secretariat Press, (1965).

16. Kumar Balwant., et al. Diversity studies in plant and ratoon crops for selection of profitable sugarcane genotypes tolerant to water logging". International Journal of Current Microbiology and Applied Sciences 7.8 (2019).

17. Kumar and Balwant. "Genetic divergence in sugarcane ratoon for productive traits and identification of better ratooner tolerant to water logging situation". Journal of Pharmacognosy and Phytochemistry 8.2 (2019): 1688-1693.

18. Kumar Praveen., et al. "Genetic variability, heritability and genetic advance of quantitative traits in sugarcane". International Journal of Chemical Studies 6.4 (2018): 3569-3572.

19. Kumar Balwant., et al. "Variability Studies and Frequency Distribution for Yield and Juice Quality Traits of Sugarcane Ratoon Under water logged situation". International Journal of Chemical Studies 7.2 (2019): 1315-1320.

20. Kumar Praveen., et al. "Assesment of genetic parameters for various productive traits in early maturing sugarcane". International Journal of Current Microbiology and Applied Sciences 7.5 (2018): 1387- 1392.

21. Kumar Praveen., et al. "Genetic variability study for yield and Associate characters in early maturing sugarcane". International Journal of Current Microbiology and Applied Sciences 7.7 (2018): 3254-3260. 
22. Kumar P., et al. "Estimation of Extent of Variability for various traits in Sugarcane under waterlogged condition". International Journal of Current Microbiology and Applied Sciences 6.7 (2017): 1187-1192.

23. Kumar P., et al. "Study of inter-relationship and cause-effect of yield and its attribute of sugarcane under waterlogging condition". The Bioscanean International quality Journal of Life Sciences 12.2 (2017): 1131-1135.

24. Kumar Balwant and Pandey SS. "Association between response indices, stability parameters and their comparison for stability of sugarcane genotypes". Journal of Sugarcane Research 6.2 (2016): 85-99.

25. Kamat DN., et al. "Study of Physiological traits in Sugarcane under rainfed condition". Indian Sugar (2004): 985-988.

26. Kumar, Balwant., et al. '“CoP 112' - An early maturing and high yielding sugarcane variety for commercial cultivation of Bihar". Indian Journal of Sugarcane Technology 32.2 (2017): 6067.

27. Kumar, Balwant., et al. “'CoP 09437' - An identified sugarcane variety and a better option for high yielding under North Central and North Eastern Zones of India". Indian Journal of Sugarcane Technology 31.2 (2016): 50-54.

28. Kumar Balwant., et al. “"CoP 2061”- A released and notified midlate maturing sugarcane variety for Bihar, Eastern Uttar Pradesh, Assam and West Bengal". Indian Journal of Sugarcane Technology 30.2 (2015): 63-66.

29. Kumar P., et al. "Study of inter-relationship and cause-effect of yield and its attribute of sugarcane under waterlogging condition". The Bioscanean International quality Journal of Life Sciences 11.4 (2017): 3149-3153.

30. Kumar Balwant., et al. "Phenotypic stability for yield and quality in sugarcane (Saccharum spp.)”. Indian Sugar 59.11 (2010): 33-37.

31. Kumar Balwant., et al. "Genotype X Environment interaction $\mathrm{f}$ and adaption in sugarcane under nort Bihar condition". Indian Institute of Sugarcane Research 25.1\&2 (2010): 33-38.

32. Kumar, Balwant., et al. "Choice of ideal sugarcane clone for North Bihar". Indian Sugar (2006): 43-48.

33. Kumar Balwant., et al. "Performance of some sugarcane (Saccharum officinarum L.) varieties for yield and quality traits in varying environment”. RAU J. Research 14.1 (2004): 12-14.

34. Neelofer Sara and Kumar Balwant. "Estimation of Variability in Red Rot Inoculated and Un- Inoculated Early Maturing Sugarcane Clones for Cane Yield and Juice Quality Traits". International Journal of Current Microbiology and Applied Sciences 6.10 (2017): 2347-2359.
35. Padmanbhan SY., et al. “Control of sugarcane seedlings disease and nematodes”. Proc.29 ${ }^{\text {th }}$ Ind. Sc. Cong. (1942): 218.

36. Pandey SS., et al. "Selection of sugarcane clones under waterlogged condition in Bihar”. Indian Sugar 60.3 (2010): 31-34.

37. Playne, S. Bengal And Assam, Behar And Orissa (1917)-Their History, People, Commerce, and Industrial Resource, The Foreign and Colonial Compiling and Publishing Co.27 pilgrim street, LONDON, EG. An account of the districts of Bihar and Patna in 1811-1812 (1917): 2 (1936) Francis Hamilton, Bihar Research Society, Patna.

38. Sethi DR and Khanna KL. "A summary of performances of some important Coimbatore sugarcane seedling in Bihar and Orissa". Agriculture and Livestock India 5.3 (1935): 199-217.

39. Ranjan R and Kumar Balwant. "Study of Genetic Variability for Cane Yield and its Component Traits in Early Maturing Sugarcane". International Journal of Current Microbiology and Applied Sciences 6.10 (2017): 1739-1748.

40. Ranjan Relisha., et al. "Association between different productive traits for high cane and sugar yield in early maturing sugarcane". Journal of Pharmacognosy and Phytochemistry 7.5 (2018): 289-295.

41. Sahu, R.S., et al. "Index Selection in inter varietal crosses of sugarcane (Saccharum spp. Hybrid.)”. Indian Journal of Sugarcane Technology 25.1-2 (2010): 25-28.

42. Sinha SK., et al. "Screening of Sugarcane Genotypes for quality jiggery production and healthy life". Society for Recent Development in Agriculture Pr. Agriculture 15.2 (2015): 263-267.

43. Shiva Pujan Singh., et al. "Economics Analysis of Production, Resource Use Efficiency and Constraints Analysis of Sugarcane Cultivation in East Champaran District of North Bihar". International Journal of Current Microbiology and Applied Sciences 7.10 (2018): 512-519.

\section{Assets from publication with us}

- Prompt Acknowledgement after receiving the article

- Thorough Double blinded peer review

- Rapid Publication

- Issue of Publication Certificate

- High visibility of your Published work

Website: www.actascientific.com/

Submit Article: www.actascientific.com/submission.php

Email us: editor@actascientific.com

Contact us: +919182824667 